\title{
The Implementation of Scientific Approach to Improve Students' Learning Outcome by Applying Cooperative Learning Through the Material of Nationalism and Patriotism
}

\author{
Rina Fuji Riyanti, Suhanadji, Totok Suyanto \\ Universitas Negeri Surabaya \\ Surabaya, Indonesia \\ fujirina83@gmail.com
}

\begin{abstract}
- this research is based on students' activity in social science learning phenomena in grade IVB at SDN Barengkrajan II. It is marked and started by the test result which is still below the minimum completeness criteria. The minimum completeness criteria used by the school is 80. In the learning process of Social Sciences, teachers tend to apply the lecture method in learning. The purpose of this research was to improve student's activity and learning outcomes by applying scientific approach in Social Sciences learning in term of Nationalism and Patriotism Attitude theory. This research method was Classroom Action Research (CAR). This research was conducted in two cycles. The subjects of the study were students of grade IVB, consisting of 32 students. Results from cycle $I$ is seen from the results of student evaluation. The percentage reached $55 \%$ with sufficient category while in the second cycle it has increased to $\mathbf{9 5 \%}$ with good category. Based on the results of research can be concluded that the application of scientific approach can increase the activity and students' learning outcomes of IVB grader on learning Social Sciences in case of nationalism and patriotism material.
\end{abstract}

Keywords - Scientific Approach, Cooperative Learning Social Sciences, Activity, Learning Outcomes.

\section{INTRODUCTION}

In SDN Barengkrajan II especially Class IV B Researcher as a teacher found some problems in the learning process. They are stated as follow: (1) $25 \%$ or as many as 8 students of 32 students are active in following the learning with good results, while the other or $75 \%$ or as many as 24 students are in the medium category and very passive in following the learning process, (2) if they are given the opportunity to ask by the teacher, only 12 children or $37.5 \%$ want and dare to ask or put forward opinions (3) $56.25 \%$ or as many as 18 students of 32 students' daily test results are still below the Minimum Criteria of Completeness (KKM).

The above phenomenon is caused by the learning process which is still classical and teachers-oriented. Teacher acts as the center of the lesson so that the learning atmosphere becomes saturated and the class sometimes becomes less conducive. Learning should foster an atmosphere in such a way that learners actively ask question, and propose ideas. Learning is the process of giving knowledge, not just receiving a teacher's lecture. Active learning is a learning process that fosters learning dynamics for learners. Dynamics to articulate the ideas and confront the idea with the realm of reality it faces.

\section{PROBLEM FORMULATION}

Based on the limitation of the above phenomenon, the problems in this study are formulated as follows:

1. What Application of the Scientific Approach of Cooperative Learning Strategy through the attitude of nationalism and patriotism that can increase the activity of students at grade IVB in SDN Barengkrajan II Krian, Sidoarjo Subdistrict academic year 2017-2018?

2. Can the Application of the Scientific Approach to Cooperative Learning Strategy through the attitude of nationalism and patriotism improve students' learning outcomes at grade IVB in SDN Barengkrajan II Krian, Sidoarjo District academic year 2017-2018?

\section{RESEARCH OBJECTIVES}

1. To describe the activity of students in learning with scientific approach to the material of nationalism and patriotism at grade IVB in SDN Barengkrajan II Krian Sidoarjo District.

2. To know the improvement of students' learning outcomes of grade IV B with a scientific approach to the material of nationalism and patriotism in SDN Barengkrajan II, Sidoarjo regency.

\section{METHODS}

This research was a class action research, because the research was done to solve the problem of learning activities in class. Classroom action research was used in real situations, because the main focus is solving real problems in the field (Punaji, 2010: 43). Classroom action research is a study that aims to improve the quality of the learning process and outcomes in the classroom, or to solve classroom learning problems that 
are cyclical. This CAR learning model uses collaborative classroom action research model, the researchers collaborate with teacher of grade IVA of SDN Barengkrajan II. The model used as a reference was a CAR cycle model developed by Kemmis and Taggart.

Procedures which were taken in the implementation of TOD include: (1) action planning, (2) implementation of action, (3) observation, and (4) reflection. In action planning, the researcher explains what, why, when, where, by whom, and how the actions were performed. At this stage of implementation, there was an implementation or implementation of the contents of the design, which provides action in the classroom. At the observation stage, observation was done when teachers applied the action in learning. In the reflection phase, the researcher evaluated what had been done by the teacher. If the result was not in accordance with the indicator set, it was necessary to draw up a revised action plan for the implementation of the next cycle action.

\# Stage planning include:

1. Identify and analyze the problem

2. Determine the reason why the research is done, what is the main cause behind this CAR.

3. Formulate a clear problem

4. Define the way to find answers and actions

5. Establish an instrument for data collection, how to analyze it, and establish the indicators of success

6. Compile the draft action in detail

\#Stage actions were covering:

1. Deliver the opening of learning, with apperception

2. Explain the learning objectives to be achieved

3. Explain the steps of learning

4. Divide the students into study groups

5. Distribute student worksheet to each group

6. Collecting students' work

\# Stages of observation include:

1. Researchers observe and record everything that happens during the action

2. Documenting students' activities in learning and analyzing them

3. Documenting students' learning outcomes and calculating class average and classical completeness

\# Stages of reflection include:

1. Assess the actions that have been performed based on the collected data in cycle I

2. Review the strengths and weaknesses of actions that have been performed, based on observational data and cycle I tests

3. Plan the solution as a basis for improvement in the next cycle or cycle II

4. Identify constraints that may be encountered and estimate the consequences and implications of the planned action

Success Indicators

This research is said to be successful when it has achieved the following indicators of success:

1. This research is said to succeed if the students' value completeness in learning achievement reaches (minimum completeness criteria) $\mathrm{KKM} \geq 80$. Minimum value is in accordance with Minimum completeness Criteria (KKM) which is determined in SDN Barengkrajan 2 District Krian Sidoarjo District.

2. For student learning outcomes. Classic completeness should at least reach $80 \%$ or in another word, their grade should be 80 or more

\section{RESEARCH RESULTS}

Result of observation of student activity as a whole both at first and second meeting in cycle I was as many as 55\%. This value has not reached the percentage of success or completeness which should be $80 \%$. So, teachers need to make some changes to make it better than before, this was done in cycle II. The result of student activity observation as a whole both at first and second meeting in cycle II was as many as $95 \%$. This value has reached the percentage of success or completeness of $80 \%$. So that teachers have been declared successful in learning to use a scientific approach with cooperative learning strategy so that no more cycles.

Students' achievement in each cycle shows significant differences. The average score of students' learning outcomes in the first cycle is still below the minimum completeness criteria that is $55 \%$. It increased to $95 \%$ in cycle II, from 32 students who follow the learning only two people whose value is below minimum completeness criteria in cycle II. The solution for the students who are failed is to provide remidial. Differences in value from cycle I to cycle II can be presented as the evidence that learning by using a scientific approach with cooperative learning strategies can improve student learning outcomes. Based on the discussion of research results above, there is a close relationship between students' activity with learning outcomes. The increased students' activity also increases the learning outcomes.

\section{CONCLUSIONS}

The conclusion of the study can be seen as follow:

1. Application of scientific approach with cooperative learning strategy can increase students' learning activity in Social Sciences learning in term of nationalism and patriotism material of grade IV, SDN Barengkrajan II Krian, Sidoarjo regency. The increase can be seen from the result of cycle II which has reached the success indicator of this research. Research is said to be successful in the learning process if the student activity reaches $\geq 80 \%$. The average percentage of students' activity that has been achieved in cycle II was $95 \%$. This means that students' activity has improved significantly. 2. The results of students' learning outcome at grade IV, SDN Barengkrajan II Krian, Sidoarjo regency on social science has increased significantly. The increase can be seen from the result of cycle II which has reached the indicator of the success of this research. Completeness of learning outcomes achieved if the value of students reach minimum completeness criteria $\geq 80$ and classical completeness is said to be achieved if $80 \%$ of students have been completed. Indicator has been achieved in cycle II where the average value of students was 87 and the percentage of classical completeness reached $95 \%$. 


\section{SUGGESTIONS}

Based on the results of research, the suggestions are stated as in the following:

1. Teachers should use scientific approach in social science subject.

2. It needs to do further research related to the application of scientific approach on the material and other contexts.

\section{REFERENCES}

[1] Suharsimi Arikunto, Research Procedures A Practice Approach, Jakarta, PT Rineka Cipta, 1998,

[2] Suharsimi Arikunto, Research Procedure of a Practical Approach, Jakarta, PT Rineka Cipta, 1999,

[3] Suharsimi Arikunto, Fundamentals of Educational Evaluation, Jakarta: PT Bumi Aksara, 2013,

[4] Suratopo Bintarto, Geography Analysis Method, Jakarta: LP3ES, 1991

[5] J. S. Bruner, The Process Of Education, Cambridge, MA; Harvard University Press, 1962

[6] Ramlan Gani, A. Fitriyah, Mahmudah, Discipline in Indonesian, Jakarta: FITK PRES, 2011

[7] Muslimin Ibrahim, Fundamentals of Teaching Processes, Surabaya: Unesa University Press, 2010

[8] Kemendikbud, Scientific Approach (Scientific) in Learning, Jakarta: Pusbang Prodik, 2013.

[9] National Education. Journal of National Seminar of FMIPA UNDIKSHA.3, 2013.

[10] Nana Sudjana, The Basics of Teaching and Learning, Bandung: Sinar Baru Algensindo, 2009

[11] Agus Suprijono, Cooperative Learning Theory and Applications Paikem, Yogyakarta: Learning Library, 2010 